\title{
THEEFFECTS OF CURCUMA RHIZOME EXTRACT (Curcuma xanthorrhiza Roxb.)TREATMENT USING VARIOUS DOSES TOWARDS ENDOMETRIAL THICKNESSIN MICE (Mus musculus) TREATED WITH MONOSODIUM GLUTAMATE (MSG)
}

\author{
Fidia Rizkiah Inayatilah
}

\author{
Department of Pharmacy Faculty of Medicine and Health Sciences Universitas Islam Negeri \\ Maulana Malik Ibrahim Malang
}

Corresponding author: fidia_rizkiah@yahoo.com

\begin{abstract}
Monosodium Glutamate (MSG) is a food seasoning that is widely used. Consumption of MSG in excessive doses can cause an excess of free radicals in the body that trigger oxidative stress and finally affect the reproductive system hormones. These free radicals can be suppressed by administration of antioxidants. Rhizomes of Curcuma xanthorrhiza extracts containantioxidants and they are widely grown. Theyare used as traditional medicine in Indonesia. This experiment was conducted to investigatewhether rhizomes of Curcuma xanthorrhiza extracts areable to inhibit decreasing endometrial thickness in female mice after receiving orally MSG-treatment.This research adoptedtrue experimental posttest only control group design. It includes 25 mice that were divided into 5 groups: control K1 (CMC) and K2 (MSG), treatment group (MSG and rhizomes of Curcuma xanthorrhiza extracts with dose of $0,4 \mathrm{mg} / \mathrm{gBW}, 0,8 \mathrm{mg} / \mathrm{gBW}, 1,2 \mathrm{mg} / \mathrm{gBW}$ ). In addition, the mice's endometrium were removed to be subsequently stained using Hematoxillin-Eosin. Thickening of uterus was observed and measured with 40x magnitude using Microphoto Microscope Olympus. Data was analized using One Way ANOVA. The research finally comes with a result showing that there were not any significant differences discovered from the endometrium thickening from the five tested groups $(p>0,05)$. Therefore, it is implied that rhizomes of Curcuma xanthorrhiza extracts has no effect on endometrial thickness of uterus by oral MSG-treatment.
\end{abstract}

Key words: MSG, curcuma, endometrium

\section{INTRODUCTION}

The advancement of science and technology has grown rapidly in many fields. In terms of food, the advancement of technology brings both positive and negative impacts. The positive consequence is seen by the escalating quantity and quality of food as well as improved diversification, hygiene, and sanitation that become more practical and economical. The negative impact of technology advancement, in fact, is noticeably significant affecting consumer's health with spreading use of dangerous additive substances. Additive substances are chemical ingredients mixed into food to improve its quality, to enhance its flavor and to maintain its freshness.

Flavor enhancer compound that is widely and freely used is Monosodium Glutamate (MSG) or it is commonly known as vetsin. Plenty of research findings confirm that consuming MSG in excessive amount for hypersensitive people negatively affected health condition. The reported complaints included numbness, heart palpitation, nausea, headache until these were associated with "Chinese restaurant syndrome" (Sand, 2005). Further negative impact of MSG may occur if an adult consumes MSG with a dose more than $3 \mathrm{~g} /$ day while one table spoon averagely comprises 4-6 g (Walker, 2000). MSG also triggers hypertension, asthma, cancer, diabetes, paralysis and decreasing intelligence.The given MSG by $4 \mathrm{mg} / \mathrm{gBW}$ toward mice resulted in the increasing amount of malondyaldehide (MDA) in lever, kidney, and brain (Farombi and Onyema, 2006).

Camihort et al (2005) reported MSG had neurotoxic feature leading to ablation of arcuate nucleus hypothalamus axis, so the function of axis-target-hypothalamus-pituitary 
organ is interrupted. Hypothalamus secretes gonadotrophin releasing hormone that stimulates secretion of Follicle Stimulating Hormone (FSH) and Luteinizing Hormone (LH) from anterior hypophysis. Both hormones are needed for male and female gonad development since they take an important role for oogenesis process and spermatogenesis. The malfunction of hypothalamaus causes the malfunction of endocrine including reproduction hormones, which also influence the function of gonad.

Furthermore, Rosanti (2009) reported MSG was able to induce the reduction on the thickness of endometrial epithelium and the diameter of blood vessels as well as to inducethe alteration of gland configuration and stroma density. Other studies using female adult mice show MSG treatment decreased the level of estradiol, and follicle de graaf did not increase due to the disturbance by pituitary adrenal axis experienced by the treatment group (Das and Ghosh, 2011). The high consumption of MSG gave rise to excessive activation of glutamate receptors in the body. As a consequence, there was a rise in blood plasma, and the organs that had glutamate receptors, including uterus, would experience $\mathrm{Ca}^{2+}$ intensification leading to organ failure (Gill and Pulido, 2001).

Farombi and Onyema (2006) reported that the administration of MSG by $4 \mathrm{mg} / \mathrm{g} \mathrm{BW}$ (equal with $30-40 \mathrm{mg} / \mathrm{kgBW}$ for human)peritoneally could cause oxidative stress, later on resulting in Reactive Oxygen Compound (ROC). Oxidative stress is a condition where the toxic level of ROC groups exceeds the amount of antioxidant defense in the body (Syahrizal, 2008). This condition leads to the excess of free radicals that will react with fat, protein and cellular nucleic acids that cause some local dysfunctional organs. The body releases antioxidant enzymes namely SOD, catalase and glutathione, but their amount is not enough to neutralize the huge number of free radicals in the body. In fact, the number of free radicals can be minimized by natural antioxidant intake.

Curcuma is one of home remedy plants from Zingiberaceae, growing invasively and used as traditional medicinal ingredients in Indonesia (Sidik et.al. 1992). Efficacy testing on curcuma rhizomes can be obtained through empirical evidence through pre-clinical in vitro testing toward animals, and clinical testing is administrated to humans (BPOM, 2004). Curcuma rhizomes are empirically found to have many benefits. One of the potential benefits is antioxidant (WHO, 1999). The active component which is responsible for antioxidant agent contained in curcuma rhizomes is curcumin, demetoksicurcumin, and bisdemetoksicurcumin (Masuda, 1992). The study by Jitoe et. Al. 1992 depicted that the antioxidant activities derived from curcuma were more massive than the other three kinds of curcuminoid activities which were potentially found in the curcuma. Therefore, it is suspected there were other substances apart from the three substances contained in curcuma. Similarly, a study by Rao (1995) found that curcumin was more active compared to vitamin $\mathrm{E}$ and beta carotene. This is due to the role of curcumin compound structure as an antioxidant, which is able to counterbalance free radicals. The curcumin compound structure consists of phenolic hydroxyl group and beta diketone group. Phenolic hydroxyl group functions as free radical filter at the first phase of anti oxidative mechanism. In the curcumin compound structure, there are two phenolic groups, so each curcumin molecules can ward off two free radicals. Meanwhile, diketone groups function as further free radical filter in the following phase.

The more widely use of MSG was assumed to give negative effects especially toward reproduction health. The use of MSG in the long term can cause oxidative stress, and it has been proved that MSG also influences hormone activation on the reproduction system namely estrogen that has an important function in maintaining process of endometrial cycles. Based on the above explanation, this study was conducted to examine the effects of administering curcuma rhizome extract in preventing the decline of endometrial thickness infemale mice treated orally with MSG 


\section{MATERIALS AND METHODS}

This study applies true experimental post-test only control group design. The tested animals for the experiment was female mice (Mus musculus). Intervention was administrated to mice (Mus musculus) that fulfill inclusive and exclusive criteria while they were treated with MSG, and treatment group was treated with curcuma rhizome extract (Curcuma xanthorrizha Roxb.) with three different doses. This study aims at examining the effects of curcuma rhizome extract given to the mice treated with MSG toward their endometrial thickness.

\section{Instruments and materials}

Instruments used in the experiment comprise: (1) tools to extract curcuma rhizomes: oven, blender, scale, Erlenmeyer glass, glass funnel, filter paper, ethanol storage vessel, evaporator, spiral refrigerant/rotary evaporator, water pump hose, water pump, water bath, vacuum pump, bottle; (2) surgical instruments: surgical scissors, tweezers, surgical board, flacon; (3) vaginal swab instruments: cover glass, object glass, microscopes; (4) HE coloring instruments: tissue text processor, paraffin, paraffin oven, sylol solution tubes, ethanol tubes, petri dish, flacon, bottles, titration pipette, measuring glass, glass funnel, knife, timer, beaker, small box, wooden holder, spatula, refrigerator, rotary microtome with its knife, small brush, glass, covering glass, hot plate, staining jar, glass shelves, glass container, capillary pipe, blotting paper, tissue and storage box, incubation storage, Olympus microscope.

The materials for usage include: (1) materials to make curcuma rizhome extract: curcuma rizhome, ethanol solutions 70\%, aquades; (2) vaginal swab materials: Methelyn blue, alcohol, $\mathrm{NaCl}$ o,9\%; (3) HE coloring materials: mouse uterus specimen according to treatment group, color base (Harris Haematoxylin), alcohol 1\% ammoniac, contrsting color (eosin).

\section{Research Sample}

There were 25 female mice (Mus musculus) aged 1-2 months, weighing from 18-35 gram, being healthy and anatomically free from handicap.

\section{Treatment on Experimented Animal}

The experimented animals were randomly divided into five groups. Five (5) mice were grouped into a control group $1(\mathrm{~K} 1)$ with $\mathrm{CMC}$, another five mice were allocated into another control group 2 (K2) with MSG, and the other 15 mice were used as treatment groups fed with MSG + curcuma rizhome extract which were given three varying doses during 42-day treatment namely: dose 1 at $0,4 \mathrm{mg} / \mathrm{gBW}$ for group 1 , dose 2 at $0,8 \mathrm{mg} / \mathrm{gBW}$ for group 2 and dose 3 at $1,2 \mathrm{mg} / \mathrm{gBW}$ for group 3.Before surgery was administrated on the forty-third day, the mice were necessarily confirmed to be at proestrus phase indicated by the existence of mature vaginal epithelium cells from the result of vaginal testing. After that, each mouse' uterus was removed to be subsequently sent to pathology laboratory RSSA to be processed into histological specimens and to be stained using Haematoxylin-eosin. The thickness of uterus was observed, and each replication was measured with 40x magnitude using microphoto microscope Olympus at ten spots. The result of measurement, later on, was averaged to obtain the final result of the uterus thickness.

\section{Data Analysis}

The obtained data was tested in terms of its normality and homogeneity using KolmogorovSmirnov and Lavene test. As a result, all the data was normally and homogeneously distributed and the testing was continued to one-way ANOVA testing and then analyzed using SPSS 20 for windows. 


\section{RESULT AND DISCUSSION}

The measurement result toward mice'endometrial thickness as shown on microscopic specimen was presented on table 1 .

Table 1.The comparison among the effects of curcuma rhizome extract treatment with different doses to observe the endometrial thickness of mice orally treated with MSG.

\begin{tabular}{cccccc}
\hline GROUP & \multicolumn{5}{c}{$\begin{array}{c}\text { THE THICKNESS OF ENDOMETRIUM } \\
(\boldsymbol{\mu m})\end{array}$} \\
& \multicolumn{1}{c}{$\mathbf{\text { ON REPLICATION }}$} \\
\cline { 2 - 6 } & $\mathbf{1}$ & $\mathbf{3}$ & $\mathbf{4}$ & $\mathbf{5}$ \\
$\mathrm{K} 1$ & 770.3 & 695.8 & 455.9 & 381 & 505.5 \\
$\mathrm{~K} 2$ & 670.6 & 576.2 & 739.05 & 504.65 & 487.6 \\
P1 & 591.65 & 612.7 & 601.15 & 402.25 & 455.6 \\
P2 & 543 & 565.2 & 485.9 & 642.9 & 319.3 \\
P3 & 672.95 & 733.85 & 879.95 & 711.4 & 541.8 \\
\hline
\end{tabular}

The images resulted from observation toward endometrial thickness measurement obtained from each group after MSG treatment are depicted below.
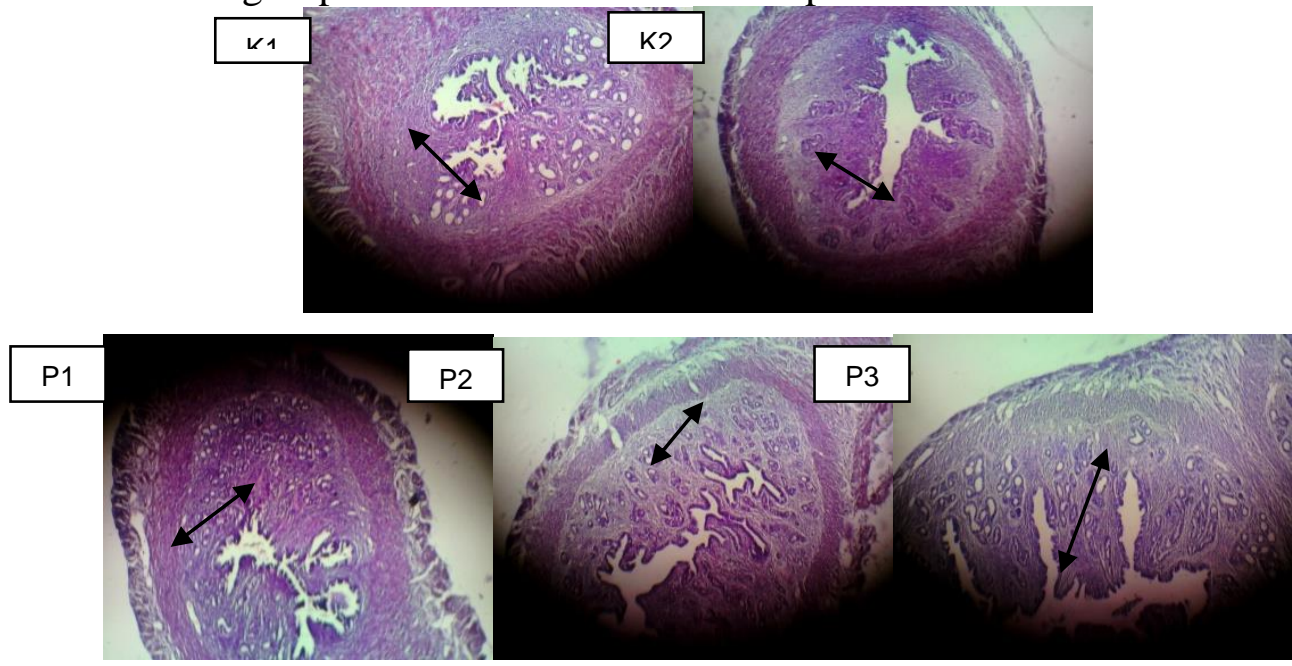

Image 1.Endometrial thickness measurement

Endometrial thickness measurement was seen at 40x magnitude using microphoto microscope Olympus and the images were processed by image Raster 3 software.Each replication was measured at ten spots, and later on it was sum up and averaged to get the final result of endometrial thickness. K1 was without MSG and curcuma rhizome extract, while K2 was treated with MSG without being given curcuma rhizome extract; P1 was treated with MSG and curcuma with $0.4 \mathrm{mg} / \mathrm{g} \mathrm{BW}$, P2 was treated with MSG and curcuma using $0.8 \mathrm{mg} / \mathrm{g} \mathrm{BW}$, and P3 was also given MSG and curcuma but with the highest dose at $1.2 \mathrm{mg} / \mathrm{g} \mathrm{BW}$.

Table 2 shows the testing result on the treatment effects of curcuma rizhome extract at various doses toward the thickness of endometrium using ANOVA. Based on the analysis result using ANOVA, p-value was found at 0.132 , greater than $\alpha=0.05$, so the testing inferred that there was no significant effect by administering curcuma rizhome extract at various doses toward endometrial thickness of mice treated with MSG. 
Table 2.The effects of curcuma rhizome extract treatment at various doses toward endometrial thickness.

\begin{tabular}{ccc}
\hline Curcuma Rizhome extract & Mean \pm SD & p-value \\
\hline K1 & $595.62 \pm 107,83$ & 0.132 \\
K2 & $554.50 \pm 158.02$ & \\
P1 & $532.67 \pm 96.85$ & \\
P2 & $511.26 \pm 121.17$ & \\
P3 & $707.99 \pm 121.54$ & \\
\hline
\end{tabular}

Glutamate is an important neurotransmitter to establish communication among neurons. Consuming Monosodium Glutamate in an excessive dose can increase glutamate in blood plasma and chemically gives rise to free radicals. In this situation, glutamate receptor works more reactively until excitotoxicity occurs.In regards to this situation, glutamate signal configuration that is required by the body to form amino acids and neurotransmitter deteriorates. Glutamate receptors are not only found in neurons but also in reproduction system including uterus. Estrogen functions critically in regulating menstrual periods and preparing implantation. Therefore, if affinity concentration RE- $\alpha$ in the uterus decreases due to the limited amount of bonded estrogen; thus, it decreases the stability of endometrium proliferation.

A study done by Wahyuni, et al., (2014) in relation with MSG treatment on female mice concluded that the MSG treatment could inhibit RE- $\alpha$ in endometrium uterus. It is supported by the evidence in which the decrease of mice's endometrium occurred while they were treated orally with MSG. This previous finding is relevant with this study, where the average thickness of endometrium obtained by K1, a group without MSG treatment, was greater than $\mathrm{K} 2$ treated with MSG.

A number of studies have proved that curcuma rhizome extract contains antioxidant. Rosidi et al (2014) in his study analyzing potential antioxidant in curcuma concluded that curcuma rhizome extract performed antioxidant activities as much as $87.01 \mathrm{ppm}$ which was classified into active; therefore, this is prospectively distinct natural antioxidant. The active ingredients accounting for antioxidant agents comprise curcumin, demetoxicurcumin, and bisdemetoksicurcumin (Masuda, 1992). Meanwhile, curcumin has crucial groups for antioxidant process. These groups consist of phenolic hydroxyl and beta diketone groups. Phenolic hydroxyl group functions as free radical filter on the first antioxidative mechanism. There are two phenolic groups in the curcumin compound structure. They allow each curcumin compound catching two free radicals. On the other hand, diketone groups function as further free radical filter in the following phase (Rao, 1995).

Karanth et al., (2001) in his study about the effect of antioxidant treatment on mice concluded that antioxidant could stimulate gonadotropin secretion ( $\mathrm{LH}$ and FSH) from adenopituitary. Ruder et al., (2008) added that antioxidant was assumed to protect endometrial tissue from oxidative stress. Al-Katib, et al., (2013) inferred that the amount of antioxidant in vitamin $\mathrm{C}$ can cause significant thickening of endometrium and increasing ovarian hormones for both fertile and infertile females if it is compared between before and after vitamin $\mathrm{C}$ treatment.A study about the effect of antioxidant treatment toward the endometrial thickness was also conducted by Wahyuni, et al., (2014). She concluded that antioxidant content in combination with vitamin $\mathrm{C}$ caninhibit endometrial toxicity caused by oral MSG treatment and to improve endometrial thickness.

Different from the previous studies stating that antioxidant contained in curcuma could elevate the endometrial thickness, this current research finding infers that there was no 
significant effect in administrating curcuma rizhome extract using various doses towards the thickness of mice's endometrium treated with MSG. Rosidi et al (2014) reporting from his study about the potential benefit of curcuma states that the antioxidant activities from curcuma rhizome extract were not as much better as Vitamin C; IC50 with 87.01 ppmfound in curcuma was equally comparable with $1.47 \mathrm{ppm}$ contained in vitamin C.Nevertheless, the data obtained from this study indicated that the average thickness of endometrium by group P3 (a group treated with MSG and rhizome extract at $1.2 \mathrm{mg} / \mathrm{g} \mathrm{BW}$ ) perceived the highest value compared to $\mathrm{K} 1$ that was not given MSG. This result assumed that curcuma rhizome extract treatment at $1.2 \mathrm{mg} / \mathrm{g} \mathrm{BW}$ allowed the thickening of mice endometrium even though the effect was not significant.

On the other hand, curcuma rhizome extract given to P1 and P2 (the groups with MSG treatment and curcuma rhizome extract at $0.8 \mathrm{mg} / \mathrm{gBW}$ and $1.2 \mathrm{mg} / \mathrm{gBW}$ ) resulted in decreasing thickness of endometrium compared to K2 which was given MSG but without curcuma rhizome extract. In contrast, Hastati and Ariani (2008) in their study concluded that Pentagamavunon-0 (analog Curcumin) treatment given to female mice could reduce endometrial thickness. Furthermore, Hastati and Ariani (2008) explained that the decrease inthe thickness which was derived from analog Curcumin treatment was assumingly caused by hypoxia from the previous situation. Hypoxia occurred due to curcumin mechanism functioning as inhibitor of COX-2 to suppress epithelial cells to proliferate, to stimulate apoptosis and to disrupt angiogenesis function contributing to decrease of endometrial thickness. Eventhough there was an average decrease in endometrial thickness occurred to P1 and P2 groups consisting of mice treated with MSG, statistically, that depletion was significant.

\section{CONCLUSION}

The administration of curcuma rhizome extract (Curcuma xanthorrhiza Roxb) using various doses did not affect significantly toward the endometrial thickness of mice (Mus musculus) treated orally with MSG.

\section{REFERENCES}

[1] Al-Katib, S.R., Meissam, M.H., Al-Kaabi, Karim, A. 2013.Effects of vitamin "C" on the endometrial thickness and ovarian hormones of progesterone and estrogen in married and unmarried women.American Journal of Research Communication.1 (8):24-31

[2] [BPOM] Badan Pengawasan Obat dan Makanan. 2004. Informasi temulawak Indonesia, Badan Pengawas Obat dan Makanan RI bekerja sama dengan Gabungan Pengusaha Jamu Indonesia, BPPOM RI

[3] Camihort, G., Gomez, D.C., Luna, G., Ferese, C., Jurado, S., Moreno, G., Spinedi, E., Console, G. 2005.Relationship Between Pituitary and Adipose Tissue After Hypothalamic Denervation in The Female Rat.A Morphometric Immunohistochemical Study.Cells Tissues Organs. 179(4): 192-201

[4] Das, R.S and Ghosh, S.K. 2011. Long-term Effects in Ovaries of The Adult Mice Following Exposure to Monosodium Glutamate During Neonatal Life.Nepal Med Coll J. 13(2):77-83

[5] Farombi, E.O and Onyema, O.O. 2006. Monosodium Glutamate-Induced Oxidative Damage and Genotoxicity in The Rat: Modulatory Role of Vitamin C, Vitamin E and Quercetin. Hum Exp Toxicol. 25(5):251-9

[6] Gill, S.S., and Pulido O.M., 2001.Glutamate Receptors in Peripheral Tissues: Current Knowledge, Future Research, and Implications for Toxicology ,J. Toxicologic Pathology, 29:208 
[7] Halliwell, B., 2007.Free Radicals in Biology and Medicine. Fourth edition. Oxford University Press.Chapter 2 and chapter 3,p.42-72.

[8] Hastati, Sri dan Ariani, Novida. 2008. Pengaruh Pentagamavunon-0 (Curcumin Analog) Terhadap Penerimaan Uterus. Jurnal Teknologi Pertnian. 4(1):12-18

[9] Jitoe, A., Masuda, T., Tengah, I.G.P., Suprapta, D.N., Gara, I.W., Nakatani,N. 1992. Antioxidant Activity of Tropical Ginger Extracts and Analysis of The Contained Curcuminoids.Journal of Agricultural and Food Chemistry.40(8):1337-1340

[10]Karanth, S; Yu, WH; Walczewska, A; Mastronardi, CA and McCann, SM (2001). Ascorbic acid stimulates gonadotrophin release by autocrine action by means of NO. Proc Natl Acad Sci USA. 98: 11783-8.

[11] Masuda, T., Isobe, J., Jjitoe, A., Nakatani, N.1992.Antioxidative Curcuminoids from Rhizomes of Curcuma xanthorrhiza.International Journal of Plant Biochemistry. 31(10):3645-3647.

[12]Rao, MNA. 1995. Antioxidant properties of curcumin. International symposium on curcimin phannacochemistry (ISCP) Yogyakarta (ID) : Fakultas Farmasi Universitas Gajah Mada bekerjasama dengan The Departement of Pharmacochemistry Vrije Universiteit Amsterdam

[13]Rosanti, Muchsin. Pengaruh Pemberian Monosodium Glutamate terhadap Histologi Endometrium Mencit (Mus musculus) [Tesis]. Medan: Universitas Sumatera Utara. 2009

[14] Rosidi, A., Khomsan, A., Setiawan, B., Riyadi, H., Briawan, D. 2014. Potensi Temulawak (Curcuma xanthorrhiza Roxb) Sebagai Antioksidan. Prosiding Seminar Nasional Hasil-hasil Penelitian dan Pengabdian

[15]Ruder, EH; Hartman, J; Blumberg, J and Goldman, M (2008). Oxidative Stress and antioxidants: exposure and impact on female fertility. Human Reproduction Update Advance Access: 1000-93.

[16] Sand, J. 2005. A short history of MSG. Good science, bad science, and tast cutlures.Gastronomica: The Journal of Critical Food Studies, 5(4), 38-49.

[17] Sidik. 1992. Temulawak (Curcuma xanthorrhiza Roxb) Di dalam: Sirait M Moesdarsono, editor. Pengembangan dan Pemanfaatan Obat Bahan Alam. Yayasan Pengembangan Obat Bahan Alam Phytomedica.

[18] Syahrizal, D.2008. Pengaruh Proteksi Vitamin C terhadap Enim Transaminase dan Gambaran Histopatologis Hati Mencit yang Dipapar Plumbum [Tesis]. Medan: Fakultas Kedokteran, Universitas Sumatera Utara.

[19] Tanaman Temu-Temuan Di Lahan Pasang Surut, Sumatera Selatan. Bul. Littro. (20) 1 : $21-30[\mathrm{WHO}]$ World Health Organization. 1999. Monograph on selected medicinal plant. Vol 1.Jenewa: WHO

[20] Wahyuni, E.D., Situmorang, C.C., Dwijayasa, P.M. 2014. Combination of Vitamin C and E Modulated Monosodium Glutamate-Induced Endometrial Toxicily in Female Wistar Rats, Asian Pacific Journal of Reproduction. 3(2):106-109

[21]Walker, R., Lupien, J. 2000. The safety evaluation of monosodium glutamate.The American Society for Nutritional Science, 130(4), 1049S-1052S. 